\title{
Tradition and Modernity in Discourses of Māori Urbanisation
}

\author{
DAN MORROW
}

\begin{abstract}
This article addresses a gap in the historical literature concerning Māori urbanisation and economic development by exploring intellectual exchanges surrounding these developments. It argues that a series of key figures transmitted a network of ideas relating to Māori acculturation and urbanisation from the inter-war through the post-war period and considers the evolution, interpenetration and divergence of their perspectives. Although primarily an examination of discourse rather than policy or resulting lived experience, the paper also traces some of the ways in which this discourse informed the actions of government officials as they attempted to manage the exodus of Māori from the countryside.
\end{abstract}

"Urbanisation, the changing employment pattern, and the rise of educational standards are throwing the Maori into closer association with European life than ever before," observed Erik Schwimmer in his 1959 essay, "Government and the Changing Maori."1 Schwimmer's paper, published in the New Zealand Journal of Public Administration, addressed state responses to the major changes facing Māori, including the post-war movement of the nation's indigenous population to cities in search of work and other opportunities. Twenty-six percent of Māori lived in towns and cities at the end of the Second World War. By 1956, this proportion had increased to 35 percent. Urban dwellers accounted for 62 percent of Māori in 1966 and nearly 80 percent by $1986 .{ }^{2}$ An expatriate German deeply read in international anthropology, Schwimmer edited the Department of Maori Affairs' monthly journal Te Ao Hou [The New World] from 1954 until 1960 and was also Advisory Officer to the Department during the 1950 s. $^{3} \mathrm{He}$ was well placed to comment on the implications of an important residential and - it seemed to him and otherscultural transition. Noting that "acculturation of the Maori progresses today at a greater rate than ever before," Schwimmer warned that recent developments-including urbanisation and changing Māori expectations — had rendered inadequate Ngāti Porou and Māori leader Āpirana Ngata's prediction that his people would not equal but approximate to "European standards." 4 The state now encouraged Māori to attain equality with the Pākehā population through economic, and to a significant extent cultural, assimilation.

Despite being viewed negatively in the early post-war period, urbanisation appeared to state planners by the late-1950s to be a great accelerant of the Māori transition toward a lifestyle more closely aligned to that of Pakeha. This transition was shortly re-labelled 'integration'. The softening of nomenclature reflected a commensurate change in policy orientation. It revealed an emergent commitment to the "combination but not fusion" of the two cultures, while signalling retreat from longstanding expectations that the dominant Pākehā ethos would subsume Māori identity. ${ }^{5}$ It is important to note, however, that assimilation remained the dominant framework, and official imaginings of New Zealand's future remained ethnically and culturally unitary in essence until at least the 1970 s. ${ }^{6}$ Schwimmer's 1959 commentary nonetheless foreshadowed the state's embrace of policy iterations incrementally more accommodating to Māori cultural difference and independence. He carefully eschewed rigid prescriptions that Māori making the transition to urban environments and occupations should be encouraged to imitate the conduct of Pākehā in all respects. ${ }^{7}$ Schwimmer instead advised that ensuring the continuity of select customary practices was necessary if Māori were to avoid floundering on "the turbulent seas of modern life." 8 Accommodation and cultural understanding were crucial to adept state management of Māori urbanisation and economic adjustment. 
Schwimmer's essay exemplified key strands of the discourse surrounding Māori urbanisation in the middle decades of the twentieth century. Central was the notion of Māori as a people struggling to reconcile communalistic modes of operation with a purportedly impersonal, transactional, individualistic, and urban way of life shared by Pākehā. Another, no less salient, characteristic of the discourse was that the Māori, possessed of a "strong desire to maintain his historical identity," should not be expected to lose contact with traditional forms of identity. ${ }^{9}$ Rather, reinforcing traditional culture would assist Māori to adapt to modern life. Schwimmer finally called for the anthropological training of civil servants and for governmentsponsored research into the "social organisation, personality structure and the changing culture of modern Maori." 10 The Department of Maori Affairs, he argued, needed to work with other government organisations and Māori leaders, deploying "intercultural workers" to advance acculturation. ${ }^{11}$ To a significant degree, this recommendation was a measure of its time. The postwar period, as Peter Mandler has pointed out, was the height of political faith in anthropologists as consultants qualified to advise governments on indigenous cultures and the relationship of ethnic majority and minority groups. ${ }^{12}$ Yet Schwimmer's recommendations also suggested a nascent awareness that changes facing Māori required a shift in the cultural orientation of administrators and Pākehā equal to, if not greater than, that being undergone by the Māori population.

University and government-based social scientists such as Schwimmer shared an appreciation for the utility of cultural traditions in helping Māori adjust to urban environments and occupational structures. The government and some Māori leaders, anthropologist Joan Metge has observed, had initially shunned the movement to cities as an unproductive "drift involving cultural and moral decline." ${ }^{\prime 13}$ This position was apparent in much newspaper coverage of the Māori urban trend from the era. ${ }^{14}$ Both Pakeha authorities and many Māori elders saw this movement into cities as hastening the dissipation of Māori culture and producing social problems. ${ }^{15}$ As late as 1954, the Department of Maori Affairs mentioned urban drift in its annual report as one regretful consequence of a lack of occupational prospects in Māori districts. ${ }^{16}$ These sentiments reflected concerns over the extent to which the rural workers would be able to adapt to the demands of a more competitive and sophisticated urban economy. The summary dismissal of city living also reflected, at least in part, a longstanding anti-urban bias in New Zealand society, whose national mythology had long drawn its energy from an imagined rural idyll. ${ }^{17}$ The negative presentation of urbanisation would return most strongly during the 1990s; when discussion of an urban Māori underclass estranged from tribal structures reached the forefront of public discourse as key Treaty settlements were negotiated.

As the post-war period progressed, economic exigencies forced a reconsideration of scepticism about the transition of the Maori population to urban environments. In particular, an escalating demand for industrial labour, which the Māori population appeared positioned to provide, engendered recognition by government that urbanisation also represented the greatest opportunity to improve Māori material standard of living, health, and share of national prosperity. Intellectual discussions of this transition were consistent, in key respects elaborated later, with an earlier insistence that the fusion of traditional and modern elements should be central to contemporary Māori identity. This paper illustrates that during the post-war period the end-goal of academic and political discussions gradually moved away from a rigid pre-war conception that assimilation was the best national future toward recognition that Māoritanga had a distinctly contemporary significance. Customary culture was increasingly understood as both expedient in helping to ease assimilation, but also valued in its own right as an anchor of Māori modernity. Various scholars including Aroha Harris, Barbara Brookes, Richard Hill, Bronwyn Labrum, Angela Wanhalla, Melissa Williams and Megan Woods have published important research on both the policy context and social experience of the Māori transition to urban 
environments. ${ }^{18} \mathrm{New}$ Zealand historians have yet to engage holistically, however, with the nature and impact of urbanisation as a historical phenomenon. Neither have scholars with urban historical perspectives thoroughly parsed the nuances and impacts of intellectual thought surrounding the Māori transition to city life. The lack of sustained attention paid to an important dynamic in New Zealand's recent urban history contrasts with a growing body of literature examining nineteenth-century urban spaces as sites of colonial contact and identity formation in the Anglophone settler colonies. ${ }^{19}$ This essay thus addresses a lacuna in the discourse by exploring intellectual exchanges surrounding the economic development and urbanisation of Māori. It examines a series of key figures involved in transmitting ideas relating to Māori acculturation and urbanisation from the inter-war through the post-war period and considers the evolution, interpenetration and divergence of their perspectives. The focus is primarily on the nature and evolution of discourse surrounding Māori movement into New Zealand cities rather than how lived experience was shaped and directed by policy. Other historians have dealt with that subject - although much work remains to be done in the area. ${ }^{20}$ It is important to note at the outset that the ideas considered in this essay are those of academics primarily, and anthropologists especially. Their ideas and writings informed the actions of government officials attempting to manage the exodus of Māori from the countryside. They thus influenced Māori lives. The ideas and actions of church and community based-intellectuals also exerted influence, but are unable to be considered within the scope of this essay.

\section{Assimilationist'native policy' in the early twentieth century and its critics: a consideration of Apirana Ngata and Peter Buck.}

In order to understand the evolution of the discourse in the postwar period, it is necessary to first discuss assimilationist "Native Policy" in New Zealand during the first half of the twentieth century. As several scholars including Graeme Butterworth and Richard Hill have pointed out, government-where it engaged at all with Māori-had long encouraged the replacement of assumedly archaic traditional cultural structures with modern European behaviours and sensibilities. The settler colonial project promised renewal in the European image as a gift to native peoples. Yet as Hill has also noted, assimilation always coexisted with Māori agency and a will for self-determination, which never went into eclipse, even during the demographic nadir of the late nineteenth century. ${ }^{21}$ This assimilationist strand of thought had been dominant in New Zealand at least since the mid-nineteenth century. The framework of assimilation, Kate Riddell has observed, while encompassing, was not overtly biological. Rather, it "allowed that Maori might survive in a physically diluted form after having 'Pakeha-ness' grafted onto them...". Yet assimilationist thought denied that Maori would ultimately survive the stresses of contact as "a separate cultural entity." 22

Partly in response to presumptions that complete cultural assimilation marked the Māori future - but also to improve general living conditions of the Māori population-a group of reformers known as the Young Māori Party emerged in 1909. The founders were former students of the academically rigorous and selective Anglican secondary school Te Aute College, located on the East Coast of the North Island. Young Māori members sought to "ameliorate the condition of the Maori race physically, mentally, spiritually." 23 They rejected expectations that Māori should strive to blithely imitate Europeans and suggestions that customary practices should be discarded in a rush to attain modern status. Instead, this group of pragmatists was concerned with improving Māori living conditions and occupational choices. For example the basis for a successful transition to modern farming as a means of uplifting the people, Ngata explained in a 1931 report to parliament on his Māori Land Development Scheme, would be a "judicious selection and combination" of elements of Māori and Pākehā culture. ${ }^{24}$ 
Despite their different fields of expertise, the two leading intellectuals in the Te Aute College Students' Association shared a concern with harnessing modern technologies and methods to meet Māori needs. Apirana Ngata was a lawyer and national politician familiar with both tribal knowledge and modern anthropological research. Peter Buck [Te Rangi Hiroa] was a trained medical doctor, who later forged an internationally significant career as an academic anthropologist. Both men drew inspiration from their exposure to literature in the burgeoning field of ethnography, as well as personal experiences as members of an indigenous culture. From the interwar period, each conceptualised a Māori-directed process of adaptation of European technologies, productive and cultural ethics to indigenous needs. Buck powerfully encapsulated this goal, asserting that: "The Maoris today do not want to go back to their old ways. They want to advance, but to be allowed to make their adaptation in such a way that certain things in their own heritage shall not perish." 25 Modernity, in Buck's formulation, could coexist with indigenous tradition and identity.

As Buck and Ngata's many writings make abundantly clear, Young Māori reformers believed that their attempts to reconcile the orientations of indigenous culture with the material aspirations and standards of European New Zealand did not suggest, in the words of Ngata "... that the movement is to turn the Māori into a Pakeha." ${ }^{26}$ Ngata's line of thought gestured toward a degree of cultural hybridity as a desirable end for Māori but, as Jeffrey Sissons has argued, continued to view tribalism as the foundation for social development, particularly for working class and more vulnerable members of the Māori population. ${ }^{27}$ This line of thought was a significant influence on the eventual erosion of the longstanding conviction that wholesale assimilation to the individualistic ethos of Pākehā society would be the inevitable consequence of Māori economic development and adjustment to a more individualist lifestyle. Ngata was critical of complete cultural assimilation because he believed that tribalism could coexist with and even encourage individual economic success. ${ }^{28}$ The policies he introduced, such as the Māori Land Development Schemes, sought to harness aspects of traditional Māori societyspecifically, tribal spirit and customary belief - to improve the economic prospects of Māori. ${ }^{29}$ Anthropologist Stephen Webster has observed, however, that there is slight evidence that Ngata ever sought to fundamentally disrupt assimilation as the framework under which Māori development would occur. ${ }^{30}$ His ideas were, in this regard, products of their time. Notwithstanding disagreement on the extent to which Ngata's thought can be considered "postassimilationist", his focus on Māori cultural autonomy certainly had an undeniable intellectual influence. ${ }^{31}$

\section{Collaboration but not fusion: Ivan Sutherland, The Maori People Today, and Inter-war anthropological discourse.}

Ngata's view that the fusion of modernity and tradition was central to a positive trajectory for Māori influenced Ivan Sutherland, an important university intellectual of the inter-war period. Following the 1924 award of his $\mathrm{PhD}$ at the University of Glasgow, Sutherland was appointed to a lectureship in Thomas Hunter's Department of Philosophy and Psychology at Victoria University College, Wellington. During the late 1920s and 1930s, he was a leading Pākehā proponent of the notion that Māori were capable of adapting their culture to the demands of modern society and that it would be unnecessary, indeed potentially counterproductive, if they were compelled to jettison customary ways. Following anthropologist Paul Radin, Sutherland also played an important role in debunking remnants of the notion that Māori were culturally disposed to resist rational thought. Ngata himself had endorsed this position as recently as the late 1920s and Sutherland is widely regarded as being influential in changing his perspective on the matter. It was Ngata, however, who convinced Pākehā intellectuals such as Sutherland that 
Māori leaders had recognized a need to move closer to Pākehā in certain economic and cultural spheres, while continuing to be a distinct and proud people. ${ }^{32}$

One of Sutherland's key contributions to the discourse of Māori modernisation was his role, while Professor of Philosophy and Psychology at Canterbury University College, as editor of The Mãori People Today: A General Survey. The idea for the volume had originated at the 1936 Yosemite conference of the Institute of Pacific Relations, where the research committee agreed to publish a symposium of the present position of the Maori people. ${ }^{33}$ This important 1940 collection, eventually published with support from the New Zealand Institute for International Affairs and from the New Zealand Council for Education Research, contained a range of essays by scholars and political figures, most prominently a discussion of the land development schemes advocated by Ngata. ${ }^{34}$ The core theme of the project, as Erik Schwimmer later observed, was that the dramatic demographic revival of the Māori people since the late nineteenth century was due both to remarkably strong leadership and strong tribal organisation and that these needed to be preserved as Māori adapted to new struggles. The volume is perhaps most notable for its vision of collaboration but not fusion of the races. In his introduction, Sutherland argued that "Maori individuality, within a blended culture partly Māori and partly European ... appears to be for the present and immediate future the most desirable policy to be pursued." ${ }^{35} \mathrm{He}$ warned later that "lacking some degree of cultural individuality and pride of race a native minority is in the greatest danger of becoming a depressed, if not despondent class existing more or less on the fringes of white civilisation." 36 "Europeanization," Sutherland argued, was a "dynamic and long evolving situation." ${ }^{37}$ Māori would "inevitably change, though change slowly...". Sutherland enjoined that "policy should be adapted" to this objective, rather than attempting to force an abrupt and culturally disruptive break with the past. ${ }^{38}$

Indeed, after 1935, under the First Labour Government, the Department of Native Affairs strove to provide economic equality to Māori, while utilising traditional structures where they were deemed useful, specifically in the tribally-based Land Development Schemes installed after 1929 under the stewardship of Apirana Ngata. ${ }^{39}$ As the economist Horace Belshaw noted in his essay in The Maori People Today, however, several factors limited the viability of plans for title consolidation and agricultural land development. Not least amongst these concerns was that persistent land alienation and individualisation of Māori title shares compelled by the operation of the Native Land Court from the late nineteenth century had ensured that the amount of land remaining in Māori hands, and the number of uneconomically sized title shares, was insufficient to support a majority of the fast growing population in agriculture in the long-term. Māori, argued Belshaw, needed to pursue a more diverse employment base. This would almost certainly involve an increased movement to urban and semi-rural areas poised to undergo economic growth in the post-war period. ${ }^{40}$ Belshaw's essay was thus the only one in the collection to engage substantively with the prospect of urbanisation-still viewed sceptically by Pākehā administrators as well as Ngata and other Māori establishment figures.

\section{Anthropological questioning of the role of tradition: Ernest and Pearl Beaglehole.}

Ernest Beaglehole, a former student of Sutherland, was the first anthropologist employed in a New Zealand University to have extensive international fieldwork experience. He was also a prominent advocate of psychology and anthropology aiding the adaptation of Māori to modern conditions. ${ }^{41}$ In 1937, the New Zealand born, London and Yale educated psychological anthropologist suggested that New Zealand "could well call upon the anthropologist to take some of the guess work out of the contact between European and native Polynesian." 42 While in the United States, Beaglehole had studied Hopi society in Arizona and worked as a consultant to the Bureau of Indian Affairs. He was appointed Senior Lecturer in Mental and Moral Philosophy at Victoria University College in 1937. In early 1938, Ernest and wife Pearl, also an experienced 
anthropological fieldworker, won a grant from the New Zealand Council for Educational Research and the Carnegie Corporation of New York to undertake what the NZCER had earlier described as "wide ranging survey of Māori life in relation to the educational needs of the people". ${ }^{43}$ The Beagleholes conducted this study in 1942 and 1943, in a Catholic Māori community based at Pukekaraka, near the town of Otaki, on the lower west coast of the North Island. The research, published in 1946 as the monograph Some Modern Maoris, provided an unusually vivid observed portrait of life in a Māori community contending with pressures of participation in a money economy. ${ }^{44}$ Although little remembered, Some Modern Maoris has been cited as a record of this transition, and as an empirical survey of racial attitudes that illustrated the social gulf separating the rural Māori and Pākehā communities at mid-century. ${ }^{45}$

The conclusions of Some Modern Maoris contradicted the prescriptions of Ngata and Buck that the transition to modernity must be graduated and based on traditional social structures. The Beagleholes instead theorised that the psychological orientation of Māori toward generosity, inculcated by customary patterns of childrearing, was irreconcilable with the individualistic ethos of Pākehā society. ${ }^{46}$ This clash of values was a major obstacle to Māori success, at least understood in material terms. The couple thus encouraged Māori to rapidly shed core cultural characteristics, and called for adult education programmes to encourage Māori to adopt the acquisitive drive, individualism, and domestic thrift presumed to constitute the ethos of Pākehā society. ${ }^{47}$ The expectation that assimilation was most conducive to successful modernisation delineated by the Beagleholes was something of a counterpoint to assertions that Māori cultural identity required careful preservation by the state and Māori themselves. The Beagleholes believed that improving the welfare of Māori probably meant hastening assimilation to a modern way of life that would involve "an ever increasing attempt to become more like Pakehas." 48 Something of this perspective initially informed more sophisticated empirical research later undertaken by the Beagleholes' student and future son-in-law James Ritchie at Murupara in the central North Island. ${ }^{49}$

After the Second World War, the migration of Māori to cities and towns intensified, becoming what Ian Poole has described as "arguably the most accelerated shift for a national population anywhere." 50 During this period, the belief held by the Beagleholes - and prior to the late-1960s by James Ritchie - that Māori should alter themselves to suit modern conditions, continued to inform policy of the Department of Native Affairs. By the 1950s, however, the department was beginning to replace assimilation as a core policy concept with the idea of integration. Although not a radical departure from the assimilative framework, integration involved the combination of the two races as an incremental and necessarily incomplete process. Proponents of integration also increasingly recognised the value of traditional structures in providing a sound base for the Māori transition to a modern lifestyle, in contrast to earlier perceptions of them as steps in the path of Māori progress. ${ }^{51}$ As Richard Hill and Aroha Harris have observed, however, policy during the 1950s and 60s remained essentially guided by assimilationist goals in its conviction that the ultimate merging of Māori and Pākehā into a single, Pākehā-oriented national culture was both desirable and inevitable. ${ }^{52}$ Tensions surrounding these changes in the discourse will be addressed in the ensuing discussion of Māori Affairs anthropologist John Booth and Minister Jack Kent Hunn.

The Auckland School and the discourse of Māoritanga: recognising essential differences. In late 1949, expatriate Australian Ralph Piddington was appointed Foundation Professor of Anthropology at Auckland University College. ${ }^{53}$ Piddington was responsible for establishing the department and held this position until he retired in 1971, although his involvement in the running of the department waned from the mid-1960s. ${ }^{54}$ During the first decade in which he was steward of the Auckland Department in particular, Piddington and members of the anthropology

Journal of New Zealand Studies NS18 (2014), 85-105 
department presented an alternative to expectations of culturally diminishing integration in the idea of symbiosis. ${ }^{\mathbf{5 5}}$ This concept envisioned New Zealand society as moving, with urbanisation and modernisation, toward a state of symbiosis in which Māori and Pākehā would coexist while recognizing essential differences between the cultures. From early in his career in Auckland, Piddington displayed a keen interest in Māori as a dynamic and adaptive people and in customary culture as a guiding source of identity during the transition to a modern economic and social paradigm. Piddington supported Maori scholars to establish the instruction of Te Reo. One of the first decisions Piddington made was to appoint Bruce Biggs, formerly a schoolteacher on the remote East Coast, as part-time lecturer of Māori. ${ }^{56}$ This was the first university appointment dedicated to the teaching of the Māori language, although some courses were offered earlier by Matiu Te Hau and Maharaia Winiata in the Adult Education programme. ${ }^{57}$ By 1952, the department offered a full lecture course in Māori Studies at Stage 1 taught by Biggs. ${ }^{58}$ With encouragement from Piddington, Biggs took leave in 1955 to begin $\mathrm{PhD}$ study at the University of Indiana at Bloomington. From the 1960s, he become a leading national figure in the promotion of Te Reo Māori as a language of academic teaching and learning, and did more than perhaps anyone to promulgate language as the foundation of contemporary Māori identity.

An older associate of the department, Maharaia Winiata, was another important participant in the argument that a degree of continued Māori cultural distinction was desirable. Born in 1912, Winiata (Ngati Ranginui) passed the public service exam as a young man and appeared to have a bright future. His plans were waylaid, however, by the onset of the Great Depression. Winiata subsequently trained as a Methodist minister and teacher and taught at Maori schools. ${ }^{59}$ In 1949, he was appointed to the role of tutor-organizer in the Adult Education programme at Auckland University College. Winiata become friends with Piddington, who assisted him in obtaining a scholarship to undertake doctoral studies at the University of Edinburgh in $1952 .{ }^{60}$ His doctoral thesis, The Changing Role of the Leader in Maori Society: A Study in Social and Race Relations, was completed in 1954 and published in shortened form after his untimely death at the age of 47 in 1960. The study, which examined changing forms of Māori leadership from pre-European times to the modern era, was the first doctorate completed by a Māori person overseas. It was also at the time one of the few studies to engage with Māori experience in the twentieth century. ${ }^{61}$ The central argument was that the institutions of Māori society had become increasingly specialised as it went through a rapid change following contact with Europeans in the nineteenth century and a process of industrialization in the twentieth. ${ }^{62}$ Winiata postulated that Māori leaders gained status from three social contexts: "Māori society, European society, and the systems and organization that originated from both Māori and European societies." ${ }^{63}$ Māori leaders, he reasoned, acquired and presumably maintained leadership status by holding a superior position in one of these spheres. But the most effective leaders were those who achieved success according to European standards and probably within European institutions, yet maintained strong respect from the Māori people. ${ }^{64}$

This focus on the evolution of Maori institutions was explored in more publically accessible terms in a March 1955 radio broadcast, "Two Peoples: One Nation." Winiata observed in the address, which was reproduced almost in entirety in the New Zealand Listener, that despite the changes wrought by urbanisation, substantive cultural integration was yet to occur as "even in cities, despite pressures from the Pākehā side, the Māori groups tended to become identified with themselves rather than the Pākehā groups surrounding them." ${ }^{65}$ Māori participated in many institutions with Pākehā, yet the existence of specialized departments to address unique group needs "represents to Maori communities something that is distinctively their own." 66 The most notable specialised agencies and political institutions were the electoral seats set aside for Māori voters in 1867, and the Native Schools run directly by the Department of Education. Since their formation to educate rural Māori in 1867, the latter had taught a European curriculum. This 
concentrated on the acquisition of the English language, and was oriented toward assimilation. ${ }^{67}$ By the beginning of the 1930s, however, educators and administrators increasingly subscribed to the 'Europeanization' or 'cultural adaptation' movement implemented by imperial authorities in Britain and widely copied by governments. ${ }^{68}$ This new framework, set out by the British government's 1925 White Paper Education Policy in British Tropical Africa, pronounced that education should be adapted to the "mentality, aptitudes, occupations, and traditions of various peoples, conserving as far as possible the sound and healthy elements in the fabric of their social life." ${ }^{69}$ Ethnic differentiation in politics and education had merit, Winiata believed, in that it provided a "compactness to the group and a degree of status in a society overwhelmingly European." Winiata expressed some reservation however, that while the system delivered a "confined scope for talented Māori," it at the same time supported the "illusion" among the "Maori minority" that "they count for something in New Zealand society, that their supposed real rights are being preserved." This impression, Winiata claimed, "helps to keep the Māori out of the mainstream of things in a place the Pākehā thinks the Māori should occupy in society."70

\section{The Hunn Report and the emergence of Integration.}

The postwar evolution of ideas about the relationship between assimilation and modernisation was crystallized in the Hunn Report, one of most contested documents in recent New Zealand history. Released in 1961, the report had been completed the previous year but not made public for political reasons in an election year. In January 1960 Prime Minister Walter Nash, who had assumed the portfolio of Māori Affairs in 1957, appointed veteran civil servant J. K. Hunn Acting Secretary of the department. Hunn was given the task of undertaking a review of Māori assets. He interpreted this to include human resources. ${ }^{71}$ In preparing the report, and devising the policy of integration delineated in the document, Hunn worked closely with John Booth, the first trained anthropologist to be employed in the New Zealand public service. Despite never holding a university appointment, Booth was an influential figure in the history of social science research in New Zealand. ${ }^{72}$ During the 1950 s, Booth, who had been educated in part at London University, co-authored reports and policy papers discussing integration, in addition to research on Panguru in Northland. ${ }^{73}$

The main body of the Hunn report consisted of a statistical profile of the current socioeconomic situation of the Māori population. This exercise in accounting revealed both known dynamics, such as a robust Maori birth-rate that outpaced that of Pākehā four to one, in addition to lesser-known disparities between the populations in areas including educational achievement, life expectancy, household incomes and general standard of living. To ameliorate this imbalance, the document asserted that a government policy of expedited economic and social integration needed to be implemented. The state would assist Māori as they attempted to raise themselves to full participation in a modern lifestyle, by providing targeted social and economic assistance, although it was hoped that the need for the provision of specialised services, indeed the existence of the Department of Māori Affairs itself, would eventually be unnecessary once enough Māori had integrated with contemporary society. The modern standard of living Māori would obtain, the document pointed out, was not determinedly Pākehā in essence but equivalent to that of other advanced non-white peoples such as the Japanese. ${ }^{74}$

The Hunn Report outlined four possible policies for modernising the Māori population. The report construed the first and most conventional policy of Assimilation, as meaning to absorb, or blend the Māori into the Pākehā culture. This would entail a complete loss of the former culture. Integration, meanwhile, was interpreted as a "combination rather than a fusion of Māori and Pākehā elements" to form one nation, albeit one in which Māori culture would remain distinct. "Segregation" implied "a theoretical concept of apartheid." The report finally listed a crude version of Piddington's symbiosis, which it defined as "to have two dissimilar peoples 
living together but as separate entities with the smaller deriving sustenance from the larger (seemingly an attempt to integrate and segregate at the same time)." 75 Of these options, integration appeared "the obvious trend" and "conventional expression of policy." "T6 The report was frank in its assessment that the urbanisation of the majority of the Māori population was both an inexorable development, given the paucity of rural landholdings, and "the quickest and surest way of integrating the two species of New Zealanders."77 The document thus advocated that the successful social and economic integration into the national mainstream would result in the elimination of a minority of Māori "complacently living a backward life in primitive conditions...", while letting a purported "main body of Maori"-comfortable in both the Māori and Pākehā worlds - choose whether to join a "completely detribalized minority whose Maoritanga is only vestigial." ${ }^{78}$ The last category was implicitly understood as the most desirable, which reflected the limitations of integration. ${ }^{79}$

The Hunn Report attracted fierce criticism, both at the time of its release and subsequently, for promulgating an ethnocentric and possibly Social-Darwinist theory of cultural adaptation. ${ }^{80}$ The criticism was at least partly warranted. The document stated that "only the fittest elements of Māori culture (worthiest of preservation) have survived the onset of civilisation". ${ }^{81}$ The report also controversially described "Language, arts and crafts and the institutions of the marae", as "relics." 82 It bears noting, however, that the policy of integration as delineated in the report did imply "some continuation of Māori culture". ${ }^{83}$ The report also acknowledged that Māori individuals would ultimately choose which elements of customary culture should be preserved. This recognition appeared to evince an appreciation of Māori agency not consistently present in previous discussions. The integrative framework, given full elaboration by Hunn and Booth in a 1962 policy document entitled "Integration of Māori and Pakeha," described "... a dynamic process by which Māori and Pākehā are being drawn together, in the physical sense of the mingling of the two different populations, as well as in the mental and cultural senses, where differences are gradually diminishing." 84 Rather than a one-way process of assimilation, Hunn and Booth saw "the integration of Maori and Pakeha as the making of a whole new culture by the combination and adaptation of the two pre-existing cultures." 85

\section{Joan Metge and the questioning of the urbanisation thesis: the persistence of kinship networks.}

Shortly after the report's publication, another important figure in the discourse of Maori integration, Joan Metge, wrote to Hunn to assure him of her "fullest support for [your] conclusions and (with a few minor reservations) for your proposals." ${ }^{86}$ Metge was the early member of the Auckland Anthropology Department who produced the most significant research into the Māori transition to urban areas and its cultural implications. Born in 1930, Metge completed an MA in Geography at the University of Auckland before enrolling in Piddington's Stage 2 Anthropology course in 1952. Under Piddington's supervision, from 1953 until 1955, she undertook a pioneering empirical study of the migration of Māori from rural northern districts to Auckland, before leaving to undertake doctoral research on a $\mathrm{PhD}$ at the London School of Economics. This research was eventually published as A New Māori Migration in 1964. Upon returning to New Zealand, Metge was at the vanguard of inter-cultural research and education in her role as Tutor-Organiser in the Continuing Education programme at Auckland University College. She later became a founding member of the Anthropology Department at Victoria University, Wellington. ${ }^{87} \mathrm{~A}$ New Māori Migration provided a rich portrait of Māori rural and urban and communities. Perhaps most significantly, however, the study can be considered something of a corrective to a presumption-widespread yet largely untested by empirical research - that urbanisation involved a cultural shift of sufficient gravity to sever or strain traditional social networks. Metge herself began with this hypothesis. This was largely due to the 
negative reception of urbanisation in the early post-war period and the international sociological orthodoxy that transition to dense urban environments hastened the disintegration of traditional kinship networks. This perspective stemmed from the work of Louis Wirth and the Chicago School of sociology. ${ }^{88}$ Metge's research, however, proved this supposition largely incorrect in the New Zealand context. ${ }^{89}$

It is important to qualify that Metge did indeed find some difference in both the structure and organisation of rural and urban Māori society. One notable experiential divergence was an absence of "historical association" of newcomers to Auckland with the urban land area-and a lack of "communal density", as Māori "had not grouped themselves into self-conscious communities on a territorial basis as in the country." 90 Many urban migrants lived scattered throughout the urban area, partly as a result of the Department of Maori Affairs policy of 'pepperpotting' housing allocation. This involved the planned dispersal of Māori in the hope of encouraging integration and avoiding ghetto formation. ${ }^{91}$ As Ranginui Walker has observed, however, inner-city slum clearance and building of public housing resulted in the reconcentration of Māori on the urban periphery from the 1960s. ${ }^{92}$ Metge described the differences between urban and rural based Māori society, however, as essentially "variations on a basic theme rather than fundamentally alien to each other. There was no social hiatus between them, no real divergence of aims and aspirations." 93 Māori society, both urban and rural, continued to be held together by "a constant interchange of personnel, by a network of kinship obligations, and by a shared Maoritanga." $" 94$

Māori living in Auckland, Metge observed, exhibited strong social ties to the country. A majority of Māori Aucklanders maintained significant relations with their home communities and were in constant communication with friends and relatives. ${ }^{95}$ This occurred both in the form of remote communication such as the telephone and, more commonly, frequent back and forth visiting. ${ }^{96}$ She noted that living in the city had in fact made occasional participation in rural social rituals more appealing to city dwellers as they got to experience the "high points of the rural year without having to endure the monotony of the intervals in between." 97 Urban dwellers felt, in this sense, that they enjoyed "the best of both worlds." 98 Māori living in Auckland also failed to display the expected departure from established systems of rural social organisation. While kinship networks had atrophied slightly in some cases, in that "Maoris living in the city had fewer effective kin especially in the city itself, they relied on them to a greater extent for constant moral support and companionship as a protection against isolation and loneliness." 99 Rather than the assumed cleavage between city and country living, Metge's research appeared to suggest that fluidity and continuity most characterised the rural-urban relationship in the era of urbanisation. ${ }^{100} \mathrm{In}$ a recent article, Nepia Mahuika has further questioned the degree of dislocation urban migrants would have felt, arguing that the very characterisation of them as migrants elides the reality that many putative newcomers to the city in fact possessed longstanding genealogical connections with the urban areas into which they were arriving. ${ }^{101}$

\section{Schwimmer and The Maori People in the Nineteen Sixties: Biculturalism and Inclusion.}

From 1954 Erik Schwimmer extended the debate over the importance of Maoritanga to contemporary Māori adaptation in a new forum: a magazine established by the Department of the Maori Affairs two years earlier. The publication, Te Ao Hou [The New World] was intended to "provide the Maori people with superior reading matter touching Maori life and culture, foster the general public's understanding of Maori people and generally advance the politics of the department." The magazine was a hugely important force in encouraging fiction and analytical writing from Maori, giving a platform to newcomers such as poet Hone Tuwhare. ${ }^{102}$ Perhaps Schwimmer's most important contributions to the magazine, however, as Graham Butterworth

Journal of New Zealand Studies NS18 (2014), 85-105

Journal of New Zealand Studies NS18 (2014), $85-105$ 
and H. R. Young have observed, was in fostering "quiet debate within the pages of Te Ao Hou on the issue of assimilation versus Maoritanga. This focussed on the whole question of cultural survival, encouraging a discussion, with all the leading Maori of the time contributing, as to whether Maori people wanted the language, institutions and customs to survive. The answer was an emphatic Yes!"103

In 1964, Schwimmer, with fellow scholars John Forster, John Palmer and James Ritchie, assembled a committee to plan a symposium on contemporary cultural issues and challenges facing both Māori and Pākehā populations in the era of urbanisation. The group was inspired by the "great usefulness of Ivan Sutherland's 1940 collection The Maori Today and believed that a similar book was needed for our generation." 104 The resulting volume, The Maori People in the Nineteen Sixties, was published in 1968 and edited primarily by Schwimmer. It comprised sixteen essays spanning a wide range of topics and perspectives. Schwimmer explained that the authors had decided collectively "not to study the Maori as though they were a self-contained group, but to concentrate on the relationship between the Maori minority and the Pakeha majority." 105 This was because, due to the "intensive contact" between the groups, "... what looks like a Maori problem is therefore likely to be essentially a strain or stress between the two groups or resulting tensions within groups and within individuals." The essays in the symposium thus each attempted to analyse an area of "intercultural" stress ranging from "child-rearing, urbanisation, intermarriage, employment, illness politics, art and literature."106 Sutherland's landmark collection of essays was effectively being updated for the era of urbanisation and increased intercultural engagement.

Among the most significant of the diverse contributions was Schwimmer's extended introduction 'The Aspirations of the Contemporary Maori.' ${ }^{107}$ As the essays in the collection apparently did not cover all the themes discussed in the 1940 volume, Schwimmer attempted in this introduction to interpolate and synthesise the most salient points of the essays in a "significant discussion of Maori land, social organisation, education and religion." ${ }^{108} \mathrm{He}$ began by criticising the government's current policy of integration-following from points made by Piddington's essay in the collection, "Emergent Development and Integration." While ostensibly referring to the "goal of racial equality in all spheres of life," Piddington quoted the wry observation of a Māori student that integration, when used as synonym for assimilation, could effectively be described as "what the shark said to the snapper." ${ }^{109}$ Schwimmer proposed that integration be replaced with either, and preferably both, of two complimentary ideas: inclusion and biculturalism. American sociologist Talcott Parsons had coined the former term in reference to the curtailed civil rights and social participation of the African-American population in the United States. ${ }^{110}$ Unlike the basic demands of black Americans for inclusion in the polity and dignity in society, the "ambitions of Maori," observed Schwimmer, were decidedly more advanced: "he [the Māori subject] has a culture which he is jealous to retain, and which he wants to be a part of mainstream New Zealand culture." 111 Schwimmer had asserted that in recent years, Pākehā had on the whole been willing to "include" Māori in national life but that, to some degree, "the Maori pleaded the right to be excluded." ${ }^{112}$ Schwimmer was referring here to an apparent Māori preference for retaining all Māori situations and venues of expression such as dedicated church services. ${ }^{113}$

As a result of this degree of conscious withdrawal, Schwimmer argued that it was perhaps most useful to consider another North American model: Canadian biculturalism. He conceded that unlike the pronounced linguistic and cultural autonomy of French Canada, biculturalism as it operated in New Zealand was a "... most unsystematic and elusive phenomenon." 114 Most New Zealanders, Māori or Pākehā, learned a single culture during childhood. Bicultural individuals - they were overwhelmingly Māori — were also familiar, however, with the expectations and values of a second culture. ${ }^{115}$ A situation of loose and organic 
biculturalism, or "pluralism" thus prevailed in the nation. In contrast to the superficial "tolerance that characterised other plural societies", however, the biculturalism that could potentially develop in New Zealand, Schwimmer contended, "presents both a deeper threat and a great opportunity: a threat because the relationship is too intimate for a mere tolerance to succeed; and an opportunity, because deeper understanding is relatively easier to achieve." 116 The opportunity to which Schwimmer referred was due to the relatively large and growing mixed race population and rate of interracial marriages, as well as what Peter Buck had described in 1940 as a lack of prejudice toward "racial intermixture." 117 Men of mixed blood such as Ngata and Buck had in fact played important roles in Māori and New Zealand society as cultural "buffers" familiar with, and able to navigate and study, both the Māori and Pakeha worlds. The unique perspectives and activities of these bicultural leaders had aided and would continue to "aid the mutual adjustment that must come from an increasing understanding between the two races." 118 The bicultural framework Schwimmer invoked was not established - according to a distinctive set of principles deriving from the Treaty of Waitangi-until the 1980s by the Fourth Labour government. It is nonetheless extremely significant that this idea had entered intellectual discourse to the extent evident here, less than a decade since the publication of the Hunn Report.

Among the many significant essays in The Maori People in the Nineteen Sixties, two pieces stand out as warranting close analysis for their distinct relevance to the issues of cultural mixture and preservation in urban environments. The first was University of Otago based anthropologist John Harré's chapter, "Maori-Pakeha Intermarriage," which examined the implications of interracial marriage in Auckland. ${ }^{119}$ Harré's conclusions were based on both an analysis of social statistics, and a small qualitative survey of those involved in mixed marriages. Harré began by layering statistics - most notably demonstrating a recent leap in the number of marriages of Māori to Pākehā evidently precipitated by increased interaction in urban environments. Harré found that 42 percent of Māori who married in Auckland in 1960 married a Pakeha person, compared to 3.6 percent of Pakeha for the same relationship. ${ }^{120} \mathrm{He}$ also reported a recent rise in marriages between Māori men and Pākehā women. This was perhaps the more significant trend given historical overrepresentation of Pākehā men in interracial relationships. ${ }^{121}$ These figures appeared to indicate that the recent movement of Māori to cities was indeed hastening the integration of the two populations in the way anticipated.

Harré wisely pointed out, however, that despite the absence of legal or firmly entrenched social barriers to interracial couplings, the two races continued to inhabit cultural spheres that were distinct and which were not frequently crossed, even in cities. ${ }^{122}$ While the increased public recreations and amenities of urban areas promised greater interaction between the two peoples of the New Zealand, Harré noted that this did not often in fact occur in practice and both Māori and Pakeha preferred to socialise primarily within racially separate groups and institutions. Interracial friendships, where they did form, originated most often in male workplaces and often reflected the lack of intimacy characteristic of the male dominated public sphere. ${ }^{123}$ While tending toward the superficial rather than intimate, these associations were nonetheless a crucial conduit, establishing mixed social contexts in which friends and romantic partners could meet across racial lines. ${ }^{\mathbf{1 2 4}}$ Harré observed that while overt parental or social prejudice toward interracial relationships was rare, particularly so long as they seemed "casual," the issue of marriage could be more contentious. ${ }^{\mathbf{1 2 5}}$ Resistance to intermarriage among Pākehā families appeared to take the form of anxiety over associations with a low class group, while Māori resistance sometimes reflected concern to preserve cultural group identity. Harré argued, however, that such reluctance was usually confined to the early stages of a relationship and jettisoned once it had become established. ${ }^{126}$ "One of the most important aspects of race relations in New Zealand," he observed, "is the extent to which qualities of the individuals are able to override the prejudice which often prevails in a generalised form." Harré contended, however, 
that "most urban Maori are already involved in a process of acculturation and intermarriage is one of the factors that may accelerate this process". ${ }^{127}$ The relationship between urban space and interracial intimacies has been examined with a focus on visual sources by Bronwyn Labrum in the article "'Not On Our Street': New Urban Spaces of Interracial Intimacy in 1950s and 1960s New Zealand," and by Angela Wanhalla in her 2013 book Matters of the Heart: A History of Interracial Marriage in New Zealand. ${ }^{128}$

The other essay in the Schwimmer collection requiring discussion in relation to urbanisation and its implications is the contribution of Auckland University lecturer I. H. Kawharu. Whereas other chapters had focussed on the significance of contemporary developments such as urbanisation for race relations, Kawharu tackled an angle on the urban Maori experience that was fresh (at least in academic discussions). ${ }^{129}$ Again using Auckland as a case study, Kawharu turned his attention to the little discussed relationship between the growing population of recent transplants to cities and the traditional owners, or tangata whenua, of those areas. The essay was significant amid the other theoretical discussions, for the way it highlighted the tangible marginalization of the members of the Ngati Whatua iwi (tangata whenua of the Auckland isthmus), whose historic settlement at Orakei had been progressively diminished by land appropriation under acts of parliaments. ${ }^{130}$ Faced with the prospect of rebuilding a marae in the remaining space, the hapu struggled to define their relationship with non-tangata whenua Māori who had come to outnumber them in their traditional territory. ${ }^{131}$ Auckland, with its unusual scale of Māori resettlement, was, according to Kawharu, an exaggerated example of a trend occurring across the country. In towns and cities "the Maori has had to turn his attention toward a fundamentally new relationship ... analytically, the relationship is between two types of social group of contrasting solidarities. It is a contrast that is revealed in matters of recruitment and inheritance of the right to establish claims over people and property." 132 Kawharu also cited the establishment of a marae at Mangere, south of Auckland city-insolubly linked with Ngati Mahuta of Tainui, yet with a self-consciously inter-tribally active and welcoming orientationas evidence of a successful negotiation of this issue. ${ }^{133}$ Following Walker, he also pointed to the emergence of interest or cultural based Māori voluntary associations in the city, which were often based in non-marae spaces. ${ }^{134}$

\section{Ranginui Walker and urban voluntarism.}

From the 1970s, Māori intellectual Ranginui Walker influentially extended Joan Metge's corrective to presumptions that urbanisation meant being wrenched from indigenous identity. $\mathrm{He}$ developed this line of thought in his 1970 doctoral thesis, "The Social Adjustment of the Maori to Living in Auckland/Maoris in the Metropolis." ${ }^{135}$ In this important empirical study of urban Maori life in New Zealand's largest city, Walker introduced a theme that he returned to in his later research, most influentially the regular "Te Korero" series of columns he wrote for the popular periodical the Listener during the 1970s and 80s. ${ }^{136}$ The essence of this idea was distilled in Walker's observation that "urbanism confronts the Maori squarely with the possibility of his social, cultural, and biological assimilation, and he reacts by sharpening his identity as a Maori vis a vis the dominant Pakeha majority." 137 A primary way in which urban Māori sought to distinguish themselves and maintain cultural identity, Walker argued, was by transplanting rural institutions to the urban environment. But the character of these institutions, he noted, morphed as a result of their changed context. The most notable trend in this direction was the establishment in the city of voluntary local civic, cultural, sports and arts and crafts clubs. ${ }^{138}$ Many such organizations, however, were adaptations of traditional structures rather than representing a complete overhaul of the social world of rural Māori communities. ${ }^{139}$ They were spaces in which urban Māori were able to maintain cultural traditions, while developing contemporary ones. The urban transition thus fostered both "creative" and "conservative" responses in Māori. ${ }^{140}$ 
Walker influentially developed his interest in voluntary association and its implications in his later writings, particularly a 1975 chapter, "The Politics of Voluntary Association." $\mathrm{He}$ would also provide an elegant summary of the significance of new cultural formations arising from urbanisation in his popular work Ka Whawhia Tonu Matu Struggle without End. ${ }^{141}$ Walker's emphasis on voluntarism and the strengthening of group identity, though affirming of a significant aspect of the urban Māori experience, did not gloss over the many real challenges associated with working-class urban lifestyle. It is important to note that Walker's work was significant for revealing, through a close study of community organization at Otara in South Auckland, the many challenges facing urban dwelling Māori. He was also one of the first scholars to examine the negative stereotyping of urban Maori communities in the press and popular culture. ${ }^{142}$ Overall, perhaps no scholar did more than Walker to raise awareness of the challenges and opportunities facing Māori in the late twentieth century. Certainly there has been no greater intellectual advocate for Māori agency in urban situations.

\section{Conclusion}

In conclusion, this essay has highlighted a salient, yet seldom explored dynamic of New Zealand intellectual history. It has demonstrated that the discourse surrounding the significance and cultural impact of Māori urbanisation in the second half of the twentieth century was constructed using an intellectual toolkit developed in part during the interwar period. This line of argument, which recognised Māori potential to actively adapt traditional culture to contemporary needs, was advanced most significantly by indigenous scholars but was increasingly adopted by Pākehā intellectuals in the postwar period. The essay has demonstrated that in the postwar decades the pre-war discourse - embedded, in both policy and intellectual conversation, in assimilationist expectations - evolved to recognise that the continuation and strengthening of Māoritanga would be essential to a positive future for Māori, particularly as they made the transition from rural to urban lifestyles. This line of argument both aimed to push the limits of government's assimilationist paradigm and emphasised the productive role Māoritanga would play in that process. As this paper has shown, the evolution of the discourse followed a discernible pattern. Intellectuals, both Māori and Pākehā, initially expressed variations on the aforementioned framework of assimilation. But this perspective then gave way to a gradual recognition that traditional culture, rather than persisting as an ornamental feature in the identity of contemporary Māori, was and would continue to play a pivotal role in shaping an increasingly urban and diverse Māori future. These ideas were a seedbed for a later sense of agency and recognition of the importance of Māoritanga and rangatiratanga in the Māori renaissance of the mid-to-late twentieth century.

\footnotetext{
${ }^{1}$ Erik Schwimmer, "Government and the Changing Maori," New Zealand Journal of Public Administration 22, no. 1 (1959): 20

${ }^{2}$ Paul Meredith, "Urban Māori - Urbanisation," Te Ara - the Encyclopedia of New Zealand, updated 22 September 2012 URL: http://www.TeAra.govt.nz/en/urban-maori/page-1.

${ }^{3}$ Joan Metge, “The Anthropologist as Citizen," Sites 3, no 2 (2006): 61.

${ }^{4}$ Schwimmer, "Government and the Changing Maori”, 20.

${ }^{5}$ J. K. Hunn, Report on the Department of Maori Affairs 24 August 1960 (Wellington, 1961), 15
} 
${ }^{6}$ Richard S. Hill, "Maori Urban Migration and the Assertion of Indigeneity in Aotearoa/New Zealand 1945-1975,” Interventions: International Journal of Postcolonial Studies 14, no. 2 (2012): 256-258.

${ }^{7}$ Schwimmer, "Government and the Changing Maori," 22.

${ }^{8}$ Schwimmer, "Government and the Changing Maori," 23.

${ }^{9}$ Schwimmer, "Government and the Changing Maori," 23.

${ }^{10}$ Schwimmer, "Government and the Changing Maori," 22.

${ }^{11}$ Schwimmer, "Government and the Changing Maori," 20-22.

${ }^{12}$ Peter Mandler, Return From the Natives: How Margaret Mead Won the Second World War and Lost the Cold War (London and New Haven: Yale University Press, 2013), xiii.

${ }^{13}$ Metge, "The Anthropologist as Citizen," 61; see also "Maori's Future: Drift to the Cities," New Zealand Herald, 5 April 1943, 4E.

${ }^{14}$ For newspaper comment on Māori urbanisation see "Maori's Future: Drift to the Cities"; "Maoris' Future: Much Aid from State," New Zealand Herald 7 April 1943, 4; "Maori in the City," New Zealand Listener, July 2, 1950, 7; "Race Relations in New Zealand," New Zealand Listener, 25 March 1955, 3; "The Maori Comes to Town," New Zealand Listener, 26 June 1964, 3.

${ }^{15}$ For a discussion of the negative presentation of urbanisation see Joan Metge, A New Maori Migration: Rural and Urban Relations in Northern New Zealand (Parkville: University of Melbourne Press, 1964), 553; Hill; “Maori Urban Migration,” 257.

16“"Annual Report of Board of Maori Affairs and of the Secretary, Department of Maori Affairs", Appendices to the Journal of the House of Representatives, Session 1954. Vol II, G9 (Wellington: Government Printer, 1955), 19.

${ }^{17}$ See Jenny Carlyon and Diana Morrow, Changing Times: New Zealand Since 1945 (Auckland: Auckland University Press, 2013), 72-80; on pro-rural identification, 417.

${ }^{18}$ See Aroha Harris, "Concurrent Narratives of Māori and Integration in the 1950s and 60s." Journal of New Zealand Studies 6/7 (2008): 139-155; Angela Wanhalla, Matters of the Heart: A History of Interracial Marriage in New Zealand (Auckland: Auckland University Press, 2013); Melissa Mautina Williams, "Back Home in the City: Māori Migrations from Panguru to Auckland 1930-1970," PhD thesis: Department of History, University of Auckland, 2011; passim; Megan Woods, "Integrating the Nation: Gendering Māori Urbanisation and Integration 1942-1969," PhD Thesis, Department of History, University of Canterbury, 2012.

${ }^{19}$ Tony Ballantyne, "Thinking Local: Knowledge, Sociability and Community in Gore's Intellectual Life 1875-1914," New Zealand Journal of History 44, no. 2 (2010): 138-152; Tony Ballantyne, Imperial Networks (Wellington: Bridget Williams, 2010); Penelope Edmonds, Urbanizing Frontiers: Indigenous Peoples and Settlers in 19th Century Pacific Rim Cities (Vancouver: UBC Press, 2010).

${ }^{20}$ Williams, "Back Home in the City," passim; Harris; “Concurrent Narratives," 139-155.

${ }^{21}$ Hill, "Maori Urban Migration,” 257, 261. 
${ }^{22}$ Kate Riddell, "Improving the Maori: Counting the Ideology of Intermarriage," New Zealand Journal of History 34 no. 1 (2000): 82.

${ }^{23}$ Peter Buck, "The Maori Renaissance," paper presented at the Seminar Conference on Education in Pacific Countries, Honolulu, 1936', 5; cited in Judith Simon, "Anthropology, Native Schooling and Māori: The Politics of Cultural Adaptation," Oceania 69, no. 1 (1998): 69

${ }^{24}$ Native Land Development Statement by the Hon Sir Apirana T. Ngata, Appendix to the Journals of the House of Representatives 1931, sessions $1 \& 2$, (G), xv; AtoJs Online,

URL:http://atojs.natlib.govt.nz/cgi-bin/atojs? $\mathrm{a}=\mathrm{d} \& \mathrm{~d}=\mathrm{AJHR} 1931-\mathrm{I}-\mathrm{II} .2 .2 .5 .10 \& \mathrm{e}=----_{---10--1-----0--}$

${ }^{25}$ Peter Buck, 'The Maori Renaissance' quoted in I. L. G. Sutherland, "Introduction,” The Maori People Today: A General Survey (Wellington: New Zealand Institute of International Affairs and the New Zealand Council for Education Research, 1940), 36.

${ }^{26}$ Ngata cited in Hill, Maori and the State, 248.

${ }^{27}$ Jeffrey Sissons, "The Post-Assimilationist Thought of Sir Apirana Ngata: Towards a Genealogy of New Zealand Biculturalism,” New Zealand Journal of History, 34, no. 1 (2000): 55; 57.

${ }^{28}$ Sissons, "The Post-Assimilationist Thought of Sir Apirana Ngata', 56.

${ }^{29}$ M. P. K. Sorrenson, "Polynesian Corpuscles and Pacific Anthropology: The Homemade Anthropology of Sir Apirana Ngata and Sir Peter Buck," Journal of the Polynesian Society 91, no. 1 (1982): 20; Sissons, 'Post Assimilationist Thought of Sir Apirana Ngata', 54.

${ }^{30}$ Steven Webster, Patrons of Māori Culture: Power Theory, and Ideology in the Maori Renaissance (Dunedin: University of Otago Press, 1998), 115.

${ }^{31}$ Hill, "Maori Urban Migration”, 258.

${ }^{32}$ Sorrenson, "Polynesian Corpuscles and Pacific Anthropology', 14.

${ }^{33}$ Oliver Sutherland, Paikea: The Life of I. L. G. Sutherland (Christchurch: Canterbury University Press, 2013), 293. For a discussion of the origins of the collection see the chapter "The Maori People Today", 290-315.

${ }^{34}$ A. T. Ngata, "Maori Settlement," in The Maori People Today, ed. I. L. G. Sutherland, 96-185; Ngata, "Tribal Organisation", in The Maori People Today, 155-82.

${ }^{35}$ Sutherland, "Introduction," in The Maori People Today, 37.

${ }^{36}$ Sutherland, "Introduction," 38-9.

${ }^{37}$ Sutherland, "Introduction," 37.

${ }^{38}$ Sutherland, "Introduction," 39.

${ }^{39}$ Sutherland, 'Introduction', 36.

${ }^{40}$ G. V. Butterworth and H. V. Young, Māori Affairs (Wellington: IWI Transition Agency/GP Books, 1989), 87. 
${ }^{41}$ Daniel Morrow and Barbara Brookes, "The Politics of Knowledge: Anthropology and Māori Modernity in Mid-Twentieth Century New Zealand," History and Anthropology 23, no. 4 (2013): 45371.

${ }^{42}$ Ernest Beaglehole, "New Zealand Anthropology Today," The Journal of the Polynesian Society, 46, no. 183 (1937): 159.

${ }^{43}$ NZCER Minutes 21 November 1935, Archives New Zealand (07010 1256 Box B).

${ }^{44}$ See Morrow and Brookes, "The Politics of Knowledge," 463.

${ }^{45}$ Ballantyne, Webs of Empire, 119.

${ }^{46}$ Ernest and Pearl Beaglehole, Some Modern Maoris (Christchurch: New Zealand Council For Education Research, Whitcomb and Toombs, 1946). See the chapter "Bringing up Children," 118-52, particularly 144-47.

${ }^{47}$ Ernest and Pearl Beaglehole; Some Modern Maoris, 333-347; Joan Metge, "Some Modern Maoris: A Review Discussion," Department of Education, Auckland University College, 1953, 6 (Summary of a Paper Communicated to the Maori Research Conference, May 1953, unpublished.

${ }^{48}$ Ernest and Pearl Beaglehole; Some Modern Maoris, 334.

${ }^{49}$ See James Ritchie, The Making of a Maori: A Case Study of a Changing Community (Wellington: Reed, 1963).

${ }^{50}$ Ian Poole, Te Iwi Maori: A New Zealand Population Past, Present and Future (Auckland: Auckland University Press, 1991), 133.

${ }^{51}$ Hunn, Report on the Department of Maori Affairs, 15; J. M. Booth and J. K. Hunn, "Integration of Māori and Pakeha," Department of Maori Affairs (Wellington: Government Printer, 1962); passim Harris, "Concurrent Narratives," 142-143.

${ }^{52}$ Joan Metge, A New Maori Migration: Rural and Urban Relations in Northern New Zealand (London School of Economics Monographs on Social Anthropology (Parkville: University of Melbourne Press, and London: University of Athlone Press, 1964), 4.

${ }^{53}$ Joan Metge, "Piddington, Ralph O'Reilly," from the Dictionary of New Zealand Biography. Te Ara - The Encyclopedia of New Zealand, updated 8 January 2014. URL:

http://www.teara.govt.nz/en/biographies/5p28/1

${ }^{54}$ Daniel Morrow interview with Joan Metge, 3 Jan 2013. Part of the reason for Piddington's decline in departmental participation was the escallation of a long-term battle with drinking. Well known in New Zealand and Australian academic circles, Piddington's heavy drinking is mentioned in Geoffrey Gray, Doug Munro and Christine Winter ed., Scholars at War: Australasian Social Scientists 19391945 (Canberra: Australian University E-Press, 2012), 68. See also Geoffrey Gray, “"A Triune Anthropologist Appears?" Gerhardt Laves, Ralph Piddington and Marjorie Piddington, La Grange Bay, 1930, Australian Aboriginal Studies, Spring 2006: 23-35.

${ }^{55}$ Dan Morrow, "Maori and Pakeha-Two Peoples or One? Ralph Piddington and Symbiosis in MidTwentieth Century New Zealand", New Zealand Journal of History 47, 2, 2013. 
56، Three Anthropology Lecturers-Auckland University Appointments", Auckland Star, 17 January 1951' copied in Joan Metge, Research Notes re Professor Ralph Piddington, University of Auckland Special Collections MSS Archives Vault 148.

${ }^{57}$ Frances Winiata and Piripi Winiata, "Winiata, Maharaia," from the Dictionary of New Zealand Biography. Te Ara - the Encyclopedia of New Zealand, updated 8 April 2014. URL:

http://www.TeAra.govt.nz/en/biographies/5w41/winiata-maharaia

${ }^{58}$ Andrew Pawley, "Obituary: Bruce Grandison Biggs FRSNZ, CBE, OBE, President of the Polynesian Society 1979-1993”, Vol. 109 No. 4: 342.

${ }^{59}$ Maharaia Winiata and Merran Frankel, The Changing Role of the Leader in Maori Society (Plymouth: Blackwood and Janet Paul, 1967), 5.

${ }^{60}$ Frances Winiata and Pipi Winiata, "Winiata, Maharaia."

${ }^{61}$ Frances Winiata and Piripi Winiata. "Winiata, Maharaia."

${ }^{62}$ Kenneth Little, "Introduction," in Maharaia Winiata, The Changing Role of the Leader in Maori Society: A Study in Social Change and Race Relations (Auckland: Blackwood and Janet Paul, 1967), 8-9.

${ }^{63}$ Winiata, Changing Role of the Leader, 23.

${ }^{64}$ Little, "Introduction," 8; Winiata, Changing Role of the Leader, 23.

${ }^{65}$ Mahariaia Winiata, “Two Peoples: One Nation,” New Zealand Listener 25 March 1955, 24.

${ }^{66}$ Mahariaia Winiata, "Two Peoples: One Nation,” 25.

${ }^{67}$ Simon, “Anthropology, Native Schooling”, 67.

${ }^{68}$ Simon, “Anthropology, Native Schooling," 61-62.

${ }^{69}$ Education Policy in British Tropical Africa (London: HM Stationary Office, 1925), cited in Simon, "Anthropology, Native Schooling," 62.

${ }^{70}$ Maharaia Winiata, "Two Peoples: One Nation,” 25.

${ }^{71}$ G. V. Butterworth and H. R. Young, Maori Affairs, 100.

${ }^{72}$ Joan Metge, “The Anthropologist as Citizen,” 62.

${ }^{73}$ J. M. Booth and J. K. Hunn, Integration of Maori and Pakeha, Department of Maori Affairs (Wellington: Government Printer, 1962); John Booth, “A Modern Maori Community”, in J.D. Freeman and W.D. Geddes, eds., Anthropology in the South Seas (New Plymouth: Thomas Avery 1959), 235-45.

${ }^{74}$ Hunn, Report on the Department of Maori Affairs, 15.

${ }^{75}$ Hunn, Report on the Department of Maori Affairs, 15.

${ }^{76}$ Hunn, Report on the Department of Maori Affairs, 15. 
${ }^{77}$ Hunn, Report of the Department of Maori Affairs, 14.

${ }^{78}$ Hunn, Report of the Department of Maori Affairs, 16.

${ }^{79}$ Hunn, Report on the Department of Maori Affairs, 16.

${ }^{80}$ Hill, State Authority, 103; Maori Synod of the Presbyterian Church of New Zealand, A Maori View of the "Hunn Report" (Christchurch, 1961), 5-44.

${ }^{81}$ Hunn, Report on the Department of Maori Affairs, 15.

${ }^{82}$ Hunn, Report on the Department of Maori Affairs, 15.

${ }^{83}$ Hunn, Report on the Department of Maori Affairs, 15

${ }^{84}$ J. M. Booth and J. K. Hunn, Integration of Maori and Pakeha, Department of Maori Affairs (Wellington: Government Printer, 1962), 2.

${ }^{85}$ Booth and Hunn, Integration of Maori and Pakeha, 2.

${ }^{86}$ Joan Metge to J.K. Hunn, 5 April 1960, Series AAMK W3074869 Box 8, Archives New Zealand, Wellington.

${ }^{87}$ Joan Metge, "The Anthropologist as Citizen," 61; see also "Māori’s Future: Drift to the Cities," New Zealand Herald, 5 April 1943, 4E.

${ }^{88}$ See Louis Wirth, "Urbanism as a Way of Life," American Journal of Sociology 44, no. 1 (1938): 124.

${ }^{89}$ Metge, A New Maori Migration, 4-6.

${ }^{90}$ Metge, A New Maori Migration, 252.

${ }^{91}$ Elsdon Craig, "Housing an Urguent Problem", Te Ao Hou, The New World, June 19 1959; 50; Jock Phillips, "The New Zealanders - Bicultural New Zealand," Te Ara - the Encyclopaedia of New

Zealand, updated 13-Jul-12 URL: http://www.TeAra.govt.nz/en/the-new-zealanders/page-12

${ }^{92}$ Ranginui Walker, Ka Whawhai Tonu Matou/Struggle Without End (Penguin: Auckland, 2004), 198.

${ }^{93}$ Metge, A New Maori Migration, 252.

${ }^{94}$ Metge, A New Maori Migration, 252.

${ }^{95}$ Metge, A New Maori Migration, 252.

${ }^{96}$ Metge, A New Maori Migration, 232-34.

${ }^{97}$ Metge, A New Maori Migration, 239.

${ }^{98}$ Metge, A New Maori Migration, 239.

${ }^{99}$ Metge, A New Maori Migration, 180.

${ }^{100}$ Metge, A New Maori Migration, 232-50.

Journal of New Zealand Studies NS18 (2014), 85-105 
${ }^{101}$ Nepia Mahuika, "Revitalizing Te Ika-a-Maui: Māori migration and the Nation.” New Zealand Journal of History 43, no.2 (2009): 133-49.

${ }^{102}$ Butterworth and Young, Maori Affairs, 99.

${ }^{103}$ Butterworth and Young, Maori Affairs, 99.

${ }^{104}$ Erik Schwimmer, "The Aspirations of the Contemporary Maori" in Erik Schwimmer ed., The Maori People in the Nineteen Sixties: a symposium (Auckland: Blackwood and Janet Paul, 1968), 9.

${ }^{105}$ Schwimmer, "The Aspirations of the Contemporary Maori," 9.

${ }^{106}$ Schwimmer, "The Aspirations of the Contemporary Maori," 9.

${ }^{107}$ Schwimmer, "Aspirations of the Contemporary Maori," 9-62.

${ }^{108}$ Schwimmer, "Aspirations of the Contemporary Maori," 10.

${ }^{109}$ Ralph Piddington, 'Emergent Development and Integration' in Schwimmer ed., Maori People in the Nineteen Sixties, 260.

${ }^{110}$ Schwimmer, "Aspirations of the Contemporary Maori," 11.

${ }^{111}$ Schwimmer, "Aspirations of the Contemporary Maori," 12.

${ }^{112}$ Schwimmer, "Aspirations of the Contemporary Maori," 12.

${ }^{113}$ Schwimmer, "Aspirations of the Contemporary Maori," 11.

${ }^{114}$ Schwimmer, "Aspirations of the Contemporary Maori," 13.

${ }^{115}$ Schwimmer, "Aspirations of the Contemporary Maori," 13.

${ }^{116}$ Schwimmer, "Aspirations of the Contemporary Maori," 14.

${ }^{117}$ Peter Buck, "'Foreword," in Sutherland, The Maori People Today, 15.

${ }^{118}$ Peter Buck, "Foreword," 15.

${ }^{119}$ John Harre, "Maori-Pakeha Intermarriage," in Schwimmer ed., The Maori People in the Nineteen Sixties, 118-31.

${ }^{120}$ Harre, "Maori-Pakeha Intermarriage," 119.

${ }^{121}$ Harre, "Maori-Pakeha Intermarriage," 121.

${ }^{122}$ Harre, "Maori-Pakeha Intermarriage," 127-128.

${ }^{123}$ Harre, "Maori-Pakeha Intermarriage,” 128.

${ }^{124}$ Harre, “Maori-Pakeha Intermarriage,” 127-128.

${ }^{125}$ Harre, “Maori-Pakeha Intermarriage," 127-128.

Journal of New Zealand Studies NS18 (2014), 85-105 
${ }^{126}$ Harre, "Maori-Pakeha Intermarriage," 129-30.

${ }^{127}$ Harre, “Maori-Pakeha Intermarriage," 131.

${ }^{128}$ Bronwyn Labrum, “"Not On Our Street': New Urban Spaces of Interracial Intimacy in 1950sand 1960s New Zealand," Journal of New Zealand Studies 14 (2013): 67-86; Wanhalla, Matters of the Heart, passim.

${ }^{129}$ I. H. Kawharu, "Urban Immigrants and Tangata Whenua," in Schwimmer ed., Maori People in the Nineteen Sixties, 177-86.

${ }^{130}$ Kawharu, "Urban Immigrants and Tangata Whenua," 176.

${ }^{131}$ Kawharu, "Urban Immigrants and Tangata Whenua," 177-78.

${ }^{132}$ Kawharu, "Urban Immigrants and Tangata Whenua," 186.

${ }^{133}$ Kawharu, "Urban Immigrants and Tangata Whenua," 179-180.

${ }^{134}$ Kawharu, "Urban Immigrants and Tangata Whenua," 178-181.

${ }^{135}$ Ranginui Walker, "The Social Adjustment of the Maori to Living in Auckland/Maoris in the Metropolis," PhD Thesis, Department of Anthropology, University of Auckland, 1970.

${ }^{136}$ For a collection of the columns see Korero / Ranginui J. Walker; compiled from the New Zealand Listener by P. Mathieson, 1986, University of Auckland Library.

${ }^{137}$ Walker, "The Social Adjustment of the Maori to Living in Auckland," 2.

${ }^{138}$ On urban associations see Walker, "The Social Adjustment of the Maori to Living in Auckland," 2, and chapter 9 of the same, 301-64.

${ }^{139}$ Walker, 'The Social Adjustment of the Maori to Living in Auckland,” 2.

${ }^{140}$ Walker, "The Social Adjustment of the Maori to Living in Auckland," 2.

${ }^{141}$ Ranginui Walker, "The Politics of Voluntary Association," in Conflict and Compromise: Essays on the Maori Since Colonisation, ed. I. H. Kawharu (Wellington: A.H \& A.W. Reed, 1975), 197-200.

${ }^{142}$ Walker, "The Social Adjustment of the Maori to Living in Auckland," 70-76. 